\title{
アクリル樹脂板とアルミニウム合金板のパンチングリベット法による締結
}

\author{
海津 浩一"1，伊藤 脩平 ${ }^{* 2}$ ，日下 正広*1，木村 真晃 ${ }^{* 1}$ ，木之下 広幸*3
}

\section{Joining of acrylic resin sheet and aluminum alloy sheet by punching rivet method}

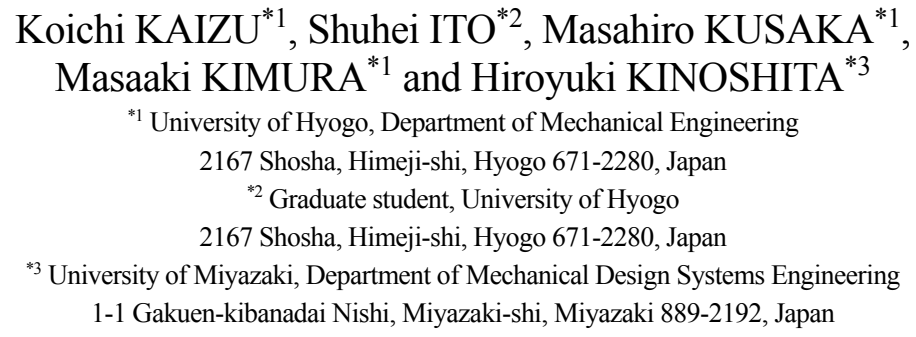

Received: 31 October 2017; Revised: 1 February 2018; Accepted: 20 May 2018

\begin{abstract}
Joining of plastics and light metals contributes to the reduction of a product weight. In this study, the punching rivet method was applied to joining of an acrylic resin sheet and an aluminum alloy sheet. The punching rivet method can join the sheets without drilling. The riveting process of this method is constituted of the punching process of the sheets using the rivet shank and the fastening process of the sheets using the rivet and the rivet holder. The sheets are fastened by using the plastic deformation of the rivet shank. From the observation of the joints made by the punching rivet method, it was found that the acrylic resin sheet of the joint had no crack and out-of-plane deformation of the joint was small. From the results of the joint strength tests, it was considered that the joint made by the punching rivet method had high strength due to the effect of the pressures on seating faces of the rivet and the rivet holder. As a result, the punching rivet method was effective to join the acrylic resin sheet and the aluminum alloy sheet.
\end{abstract}

Keywords : Machine element, Fixing element, Riveting, Joint, Punching rivet method, Resin

\section{1. 緒言}

近年，輸送機器や家電などの分野において，軽量化や高機能化が求められ，異種金属だけでなく金属と樹脂と の接合も盛んに行われている．金属とプラスチックの接合は接着剤による接着，ボルト・ナットによる機械的締 結，レーザを使った直接接合などが行われているが，それらの接合法はそれぞれに一長一短がある。接着剤は被 接着材の大きさや厚みなどに左右されず，また気密性や水密性を持つなどの優れた長所がある.しかし，その一 方で，被接着材の材質に合わせて接着剤を選ばなければならないこと，接着時間が長い場合があること，可然性 のものが多いこと，接着剤の品質管理が必要なことなどの問題点がある．ボルト・ナットの場合は，容易に接合 部をはずすことができるという極めて優れた特徵を持つが，あらかじめ穴あけなどの機械加工が必要なことから

No.17-00485 [DOI:10.1299/transjsme.17-00485], J-STAGE Advance Publication date : 4 June, 2018

*1 正員, 兵庫県立大学大学院（干671-2280 兵庫県姫路市書写 2167）

*2 兵庫県立大学大学院

*3 宮崎大学工学部（干889-2192＼cjkstart宮崎県宮崎市学園木花台西 1-1）

E-mail of corresponding author: kaizu@eng.u-hyogo.ac.jp 
作業工程が多くなること，使用されている製品が振動を受ける場合にはゆるみが発生する場合があることなどが 問題点となる．さらに，近年では軽量化と生産性の向上のためにレーザによる金属とプラスチックによる直接接 合（片山他，2007），（西本他，2013）も試みられている。レーザは瞬間的な接合が可能であるが，接合強度がレ 一ザの接合条件や材料の組み合わせに大きく影響されることが明らかになっており，さらなる研究の進展が望ま れる.このように, 現在でも金属とプラスチックの接合に関しては新たな接合法が研究され続けており,「ものづ くり」にとって非常に重要な分野となっている.

著者らは従来から締結メカニズムが簡単で高い締結強度の得られるリベット締結 (日本機械学会編, 1981)，(日 本塑性加工学会編，1990）に着目してきた。リベット締結は強度の信頼性が高く, 溶接が不可能な場合や接着性 の悪い材料を接合する場合に用いられる.しかしながら, リベット締結は被締結材に穴あけ加工が必要であり， 作業性や経済性が悪いという問題点がある (日本塑性加工学会編, 1990)。その解決手段として, セルフピアッシ ングリベット（Porcaro et al., 2006），（加藤他，2006）が用いられるようになった．セルフピアッシングリベット は穴あけ加工が必要ではなく, 締結速度が速いために生産性が非常に良いという特徽を持っている. しかしなが ら, 著者らは, セルフピアッシングリベットを用いる場合には継手の変形が大きく, 締結強度はあまり高くない などの問題点もあると考え, 通常のリベット締結に用いられている形状に近いリベットとリベットホルダーを用 い, リベットを加速した錘の打撃力を利用して高速で板へ打ち込むことによる穴あけと，リベット軸とリベット ホルダーによる板の締結を同時に行う衝撃リベット締結法（木之下他，2009，2010), (海津他, 2012) を提案し た．そして，2枚のアルミニウム合金板同士ならびに 2 枚の冷間圧延鋼板同士の締結実験を行い, 衝撃リベット 締結法により作製した継手は，締結部の変形が小さくかつ高い締結強度を持つことを明らかにした．また，この 締結法により作製した継手は継手の分解が可能であることも明らかにした．しかしながら，圧縮空気で錘を加速 させる方式を用いた衝撃リベット締結法では, 錘を加速するための長い加速管等を用いるためにスペースが必要 であり，また空気圧を用いる場合には錘の速度を精度よく制御することが難しいという問題点があった．その解 決策として, 著者らは汎用プレス機によりリベット軸を板へ押し込み, 穴あけ加工無しで板の締結を行うパンチ ングリベット法（木之下他，2011）を新たに開発した．この方法により2枚の冷間圧延鋼板同士が良好に締結で きることを示した.

通常のリベットのかしめ加工で金属とプラスチックを締結寸る場合には，あらかじめ穴あけ加工が必要なうえ に，リベット軸をかしめてリベット頭部を形成することからプラスチックに大きな荷重が作用することでプラス チックの割れにつながることがある。 またリベット軸が太りすぎて穴を押し広げることで穴の周囲にき裂を発生 させることもあり，かしめ加工を用いた金属とプラスチックのリベット締結は難しいと言える．一方，衝撃リベ ット締結法やパンチングリベット法はリベットとリベットホルダーを用いる特殊なリベット締結法であるため, 著者らは従来のかしめ加工によるリベット締結法では難しい金属とプラスチックの異種材同士の継手が比較的容 易に作製できると考えた. 本研究の最終目的は軽金属板と CFRP や GFRP などの䋊維強化複合材料板をパンチン グリベット法により締結することであるが，本報では，その第一段階として，脆性高分子材料であるアクリル樹 脂薄板とアルミニウム合金薄板をパンチングリベット法により締結することを試み，作製した異種材継手の締結 状態と強度について検討を行った。

\section{$2 \cdot 1$ パンチングリベット法による異種材継手の作製方法}

パンチングリベット法により厚さ $1.0 \mathrm{~mm}, 50 \mathrm{~mm} \times 100 \mathrm{~mm}$ の寸法のアクリル樹脂（品名：コモグラス，（株） クラレ）と同寸法のアルミニウム合金 A5052P-H34 の薄板をアルミニウム合金 A6061BD-T6 のリベットとリベッ トホルダーで締結し, 図 1 に示寸形状と寸法の継手を作製した. 図 2 はパンチングリベット法で用いたリベット 及びリベットホルダーの形状と寸法を示している. 各供試材の化学成分や機械的性質を表 1〜3に示寸.

図 3 はパンチングリベット法の概略図である. ダイスは冷間金型用鋼 SKD11 から作製し，ダイスは上部と下部 に分割されており, 図 3 は上部ダイスと下部ダイスを組み合わせた状態を示している.図 3 の下部のダイスには, 締結する板を設置する凹み部と，凹み部の中心部にリベットホルダーを設置し，リベット軸先端を開かせるため のピン及びホルダー支えを挿入する直径 $9.8 \mathrm{~mm}$ の穴を設けている. 図 3 のように上部ダイスは中心にリベット とステムを挿入する穴があり，板を下部ダイスに設置した後に上部ダイスをかぶせてボルトで板を締め付けられ 
Kaizu, Ito, Kusaka, Kimura and Kinoshita, Transactions of the JSME (in Japanese), Vol.84, No.862 (2018)

るようになっている. また，図４にSKD11 で作製したピン及びホルダー支えの形状と寸法を示しており，ホルダ 一支えに先端を円錐台状にしたピンを入れて用いた. このピンは先端の円錐部分でリベット軸の先端を開かせて リベット軸とリベットホルダーの締結を強固にするためのものである。つまり，リベット軸を圧縮して太らせる と脆性高分子材料では打ち抜かれた穴の周囲にき裂が入りやすくなることから，できるだけリベット軸先端のみ を変形させるようにした。

継手の作製は以下の手順で行った.

（1）図 3 (a) に示すように，ダイス内部に片方のリベット頭部となるリベットホルダーを設置する.そして締 結対象の 2 枚の板をそのリベットホルダーの上に設置する. さらに, その板の上面にリベットを軸の先端が 接する状態で設置し，図 3 (a) の上下のダイスをボルトにより締め付けて板を固定する. そして，ダイス の穴にステムを挿入する.

（2）図 3 （b）のように，インストロン万能試験機を用いて所定の速度でステムを介してリベットを板に押し込 むことによりリベット軸が板を打抜き，その後，リベット軸先端はリベットホルダーの穴に入る.

（3）図 3 (c) のように, リベット軸の先端がリベットホルダーの穴を通り，打抜いた小片を介してダイスに挿 入したピンに当たる. その結果, リベット軸の先端がピンにより押し広げられ，リベットホルダーとリベッ 卜頭部で板を締めつける.またリベット軸が圧縮され塑性変形して太ることでリベットホルダーの穴に充満 し板の締結がさらに強固になる.

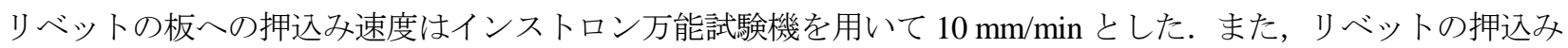
最大荷重はリベット軸とリベットホルダーが強固に締結することに留意して予備実験から $20 \mathrm{kN}$ に設定した。 ア クリル薄板とA5052 薄板の積層順が異なる継手をそれぞれ Joint A と Joint B とした. Joint A はリベット軸が打ち

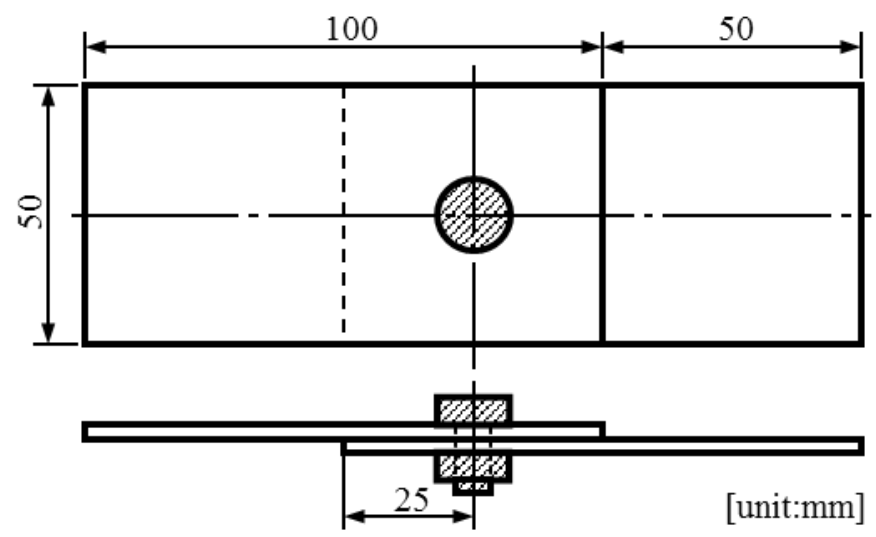

Fig.1 Shape and dimension of joint.
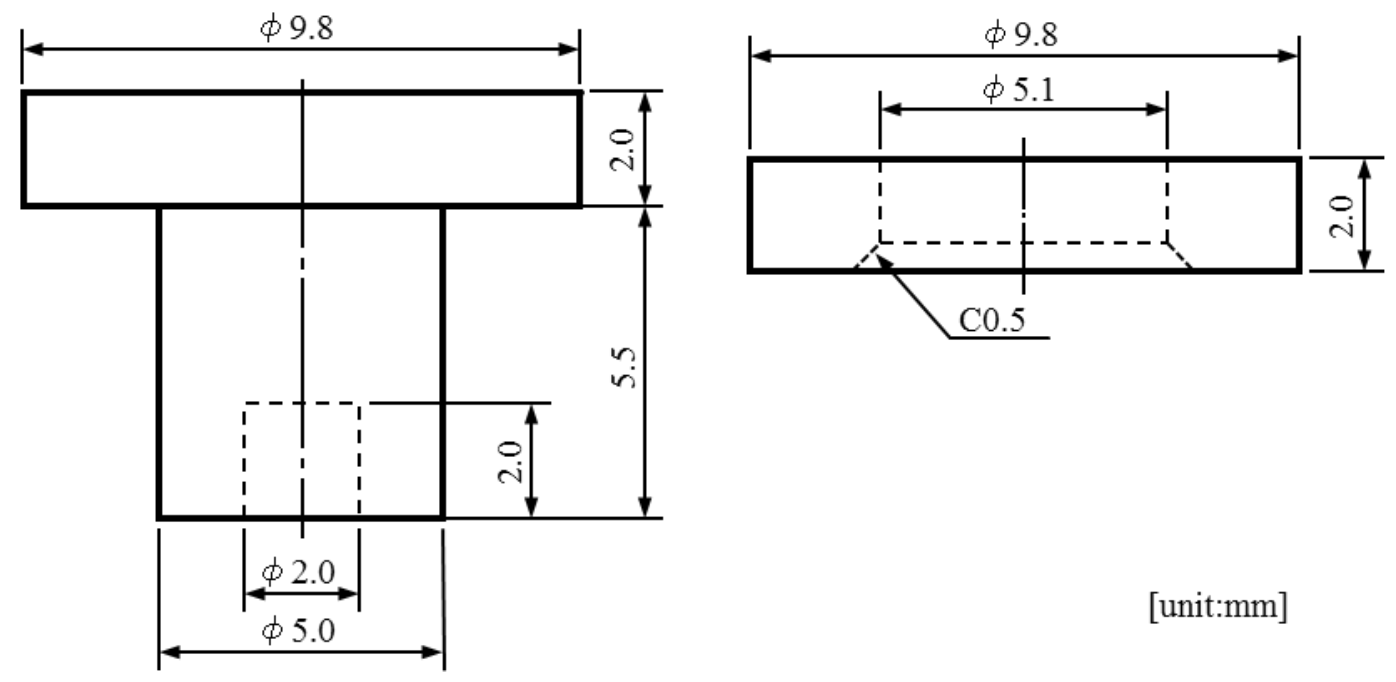

Fig.2 Shape and dimensions of rivet and rivet holder. 
Kaizu, Ito, Kusaka, Kimura and Kinoshita, Transactions of the JSME (in Japanese), Vol.84, No.862 (2018)

Table 1 Chemical composition and mechanical properties of rivet and rivet holder (A6061BD-T6).

\begin{tabular}{|c|c|c|c|c|c|c|c|c|c|c|}
\hline \multicolumn{7}{|c|}{ Chemical composition (Mass\%) } & \multicolumn{2}{c|}{ Mechanical properties } \\
\hline $\mathrm{Si}$ & $\mathrm{Fe}$ & $\mathrm{Cu}$ & $\mathrm{Mn}$ & $\mathrm{Mg}$ & $\mathrm{Cr}$ & $\mathrm{Zn}$ & $\mathrm{Ti}$ & $\mathrm{Al}$ & $\begin{array}{c}\text { T.S. } \\
(\mathrm{MPa})\end{array}$ & $\begin{array}{c}0.2 \% \text { Y.S. } \\
(\mathrm{MPa})\end{array}$ \\
\hline 0.71 & 0.3 & 0.25 & 0.11 & 1.0 & 0.18 & 0.07 & 0.02 & bal. & 332 & 303 \\
\hline
\end{tabular}

Table 2 Chemical composition and mechanical properties of Aluminum sheet (A5052P-H34).

\begin{tabular}{|c|c|c|c|c|c|c|c|c|c|c|}
\hline \multicolumn{7}{|c|}{ Chemical composition (Mass\%) } & \multicolumn{2}{|c|}{ Mechanical properties } \\
\hline $\mathrm{Si}$ & $\mathrm{Fe}$ & $\mathrm{Cu}$ & $\mathrm{Mn}$ & $\mathrm{Mg}$ & $\mathrm{Cr}$ & $\mathrm{Zn}$ & $\mathrm{Ti}$ & $\mathrm{Al}$ & $\begin{array}{c}\text { T.S. } \\
(\mathrm{MPa})\end{array}$ & $\begin{array}{c}0.2 \% \mathrm{Y} . \mathrm{S} . \\
(\mathrm{MPa})\end{array}$ \\
\hline 0.09 & 0.26 & 0.02 & 0.03 & 2.43 & 0.18 & 0.01 & 0.02 & bal. & 267 & 225 \\
\hline
\end{tabular}

Table 3 Mechanical properties of acrylic sheet.

\begin{tabular}{|c|c|}
\hline \multicolumn{2}{|c|}{ Mechanical properties } \\
\hline $\begin{array}{c}\text { Breaking strength } \\
(\mathrm{MPa})\end{array}$ & $\begin{array}{c}\text { Young's modulus } \\
(\mathrm{GPa})\end{array}$ \\
\hline 67 & 4.5 \\
\hline
\end{tabular}

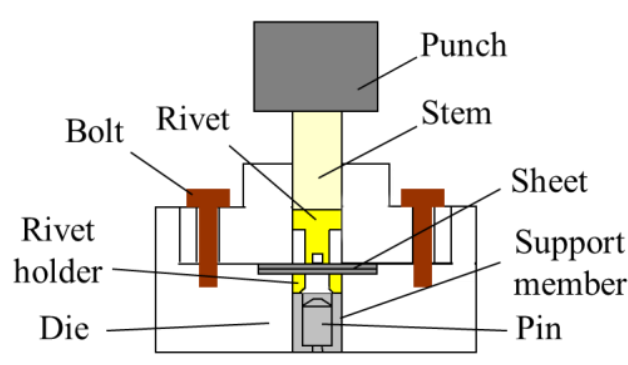

(a)

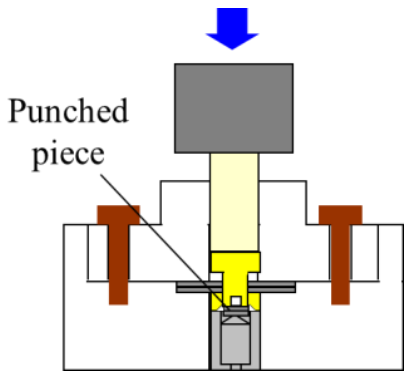

(b)

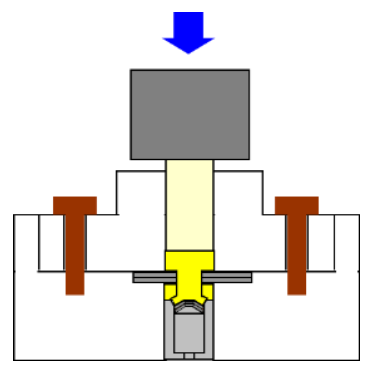

(c)

Fig.3 Schematic illustrations of punching rivet method. The punching rivet method is carried out as follows: (1) The rivet holder is inserted into the hole of the die. Two sheets without hole are set on the rivet holder. Then, the rivet is set on these two sheets, as shown in Fig.3 (a). The sheets are fixed by the bolts. (2) The rivet shank is pushed into the sheets by pressing the stem. The rivet shank punches out the sheets and enters into the hole of rivet holder, as shown in Fig. 3(b). (3) The tip of the rivet shank with punched pieces of sheets is pushed to the pin and after that plastically deformed. The sheets are fastened by the head of the rivet and the rivet holder, as shown in Fig. 3(c).
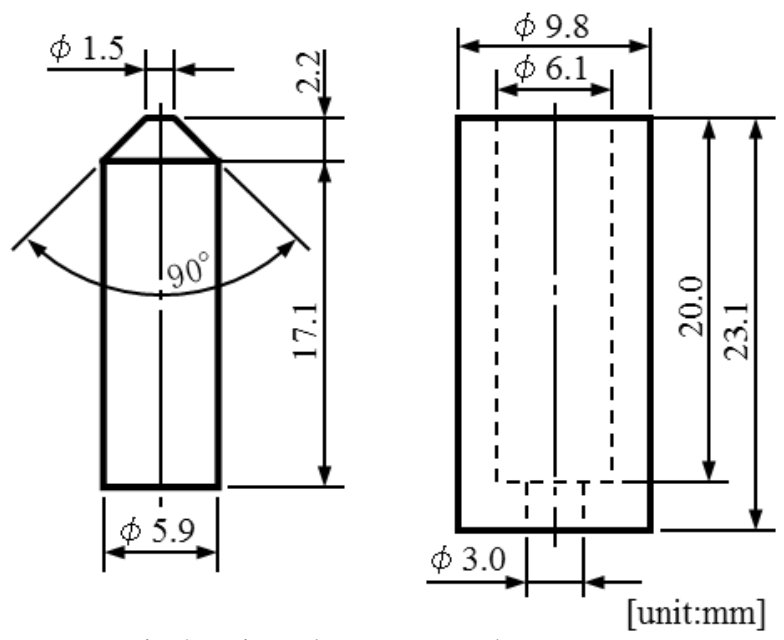

Fig.4 Pin and support member. 
抜く順番の 1 枚目がアクリル薄板， 2 枚目が A5052 薄板とした場合，Joint B は 1 枚目が A5052 薄板， 2 枚目がア クリル薄板とした場合を示すこととする．積層順の組み合わせを整理したものを表 4 に示す.

Table 4 Fastening conditions of joints.

\begin{tabular}{c|c|c}
\hline & Upper sheet & Under sheet \\
\hline Joint A & Acrylic & A5052 \\
\hline Joint B & A5052 & Acrylic \\
\hline
\end{tabular}

\section{$2 \cdot 2$ 継手の強度試験}

表 4 に示した継手の強度について検討するために，インストロン万能試験機を用いて引張試験を行った．図 5 は継手の引張試験の概略図を示している，継手の引張試験は，試験片をまっすぐに引っ張るためにつかみ部に夕 グを接着剤で貼り付け $1.0 \mathrm{~mm} / \mathrm{min}$ の引張速度で行った. また, 打抜き穴の切り口面状態が継手強度に及ぼす影響 を確認するために 2 種類の引張試験を行った．その概略図を図 6 に示す. まず，アクリル薄板と A5052 薄板にド

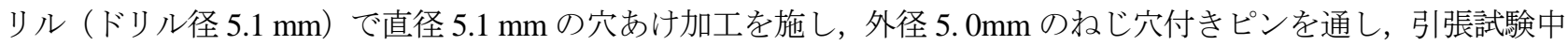
にねじ穴付きピンが斜めになり穴から抜けてしまわないように固定用筐体を被せ，数じを緩く締めた継手を作製 した．このとき，試験片はピン周りに回転でき，できるかぎり固定用筐体により板が締め付けられないようにし た．この継手をドリル穴継手（Drilled hole joint）と表記する．さらに，パンチングリベット法と同じ打抜き穴の 切り口面状態を作り出すために, パンチングリベット法と同様の方法でねじ穴付きピンを $10 \mathrm{~mm} / \mathrm{min}$ の速度で変

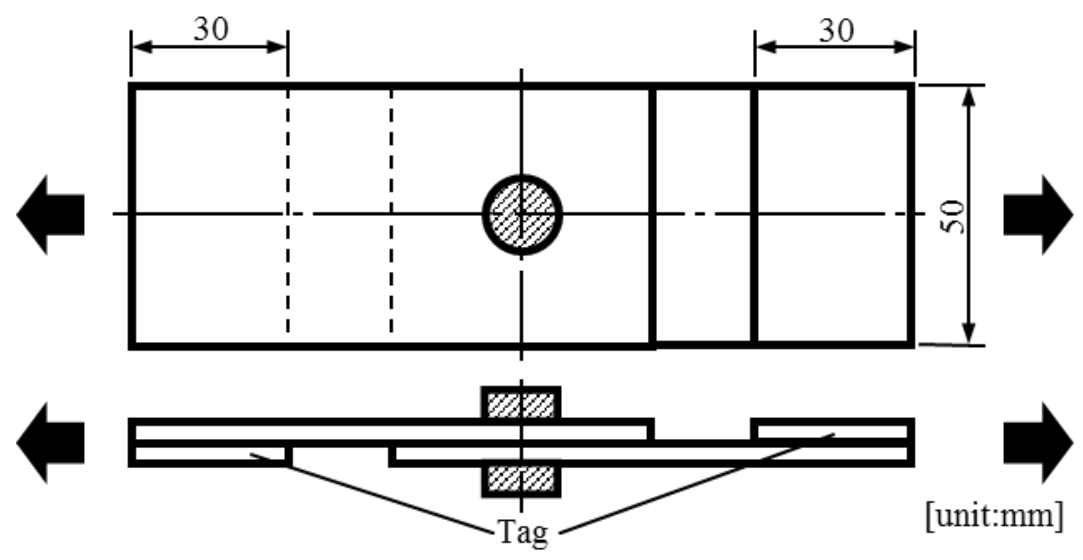

Fig.5 Tensile test of joint.
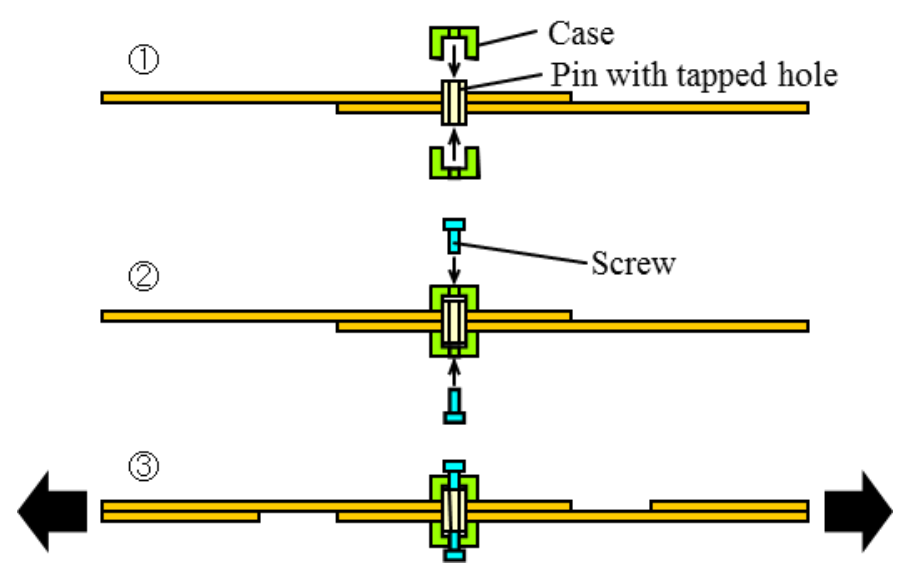

Fig.6 Tensile test for two sheets with drilled hole or punched hole under the condition the pressure on seating faces of the rivet and the rivet holder does not act. 
Kaizu, Ito, Kusaka, Kimura and Kinoshita, Transactions of the JSME (in Japanese), Vol.84, No.862 (2018)

Table 5 Experimental conditions for examining the effect of cut surface on joint strength.

\begin{tabular}{c|c|c|c}
\hline & Upper sheet & Under sheet \\
\hline \multicolumn{2}{c|}{ Drilled hole joint } & - & - \\
\hline \multirow{2}{*}{$\begin{array}{c}\text { Punched } \\
\text { hole }\end{array}$} & Type A & Acrylic & A5052 \\
\cline { 2 - 4 } & Type B & A5052 & Acrylic \\
\hline
\end{tabular}

位 $5.5 \mathrm{~mm}$ まで押し込み，図 6 のように固定用筐体を被せてねじを緩く締めた継手も作製した。このときアクリ ル薄板と A5052 薄板の積層順が異なるものを Type A と Type B とした. Type A はリベット軸が打抜く順番の 1 枚目（ダイスにセットするときに上側になる板）がアクリル薄板，2枚目（ダイスにセットするときに下側にな る板）が A5052 薄板とした場合，Type B は 1 枚目が A5052 薄板， 2 枚目がアクリル薄板とした場合を示寸ことと 寸る.これらの実験条件を整理したものを表 5 に示す．どちらの場合も試験片をまっすぐに引っ張るためにつか み部にタグを接着剤で貼り付け, $1.0 \mathrm{~mm} / \mathrm{min}$ の速度で引っ張った。 なお，パンチングリベット法の実用化のため には十字引張試験などを行う必要があるが，本論文のアクリル薄板と A5052 薄板の場合には板が薄く，十字引張 試験で強度を評価する使用法を考慮していないため本論文では行っていない。

\section{3. 実験結果および考察}

\section{$3 \cdot 1$ リベットの締結状態}

予備実験により，板を固定しないと締結強度にばらつきが生じたため，図 3 に示すダイスのボルトの締め付け トルクを $12.5 \mathrm{Nm}$ として板を固定した. このことにより, 継手強度のばらつきが小さくなったことを確認した. 図 7 に継手を作製した時の荷重一変位線図の例を示す，図 7 において, 変位 $2.0 \mathrm{~mm}$ 程度までの荷重の増減はリ心゙ ッ卜軸で 2 枚の板を打抜く過程に相当し，その後に続く荷重が低い部分は薄板の打抜き後にリベット軸の先端が リベットホルダーの穴に入る過程である. さらに, その後の荷重の上昇はリベット軸の先端が打抜かれた板の小片 を介してダイスに挿入したピンに接触し，リベット軸の先端が広がってリベット軸とリベットホルダーにより板 が締結される過程である. 板を打抜く過程において, Joint A と Joint B は打抜く最大荷重は約 4.0kN でほぼ同じで あるが, Joint A に比べて Joint B は薄板の打抜き過程が終了寸るまでの変位がやや長くなっており, 板の積層順の 影響が見られる。

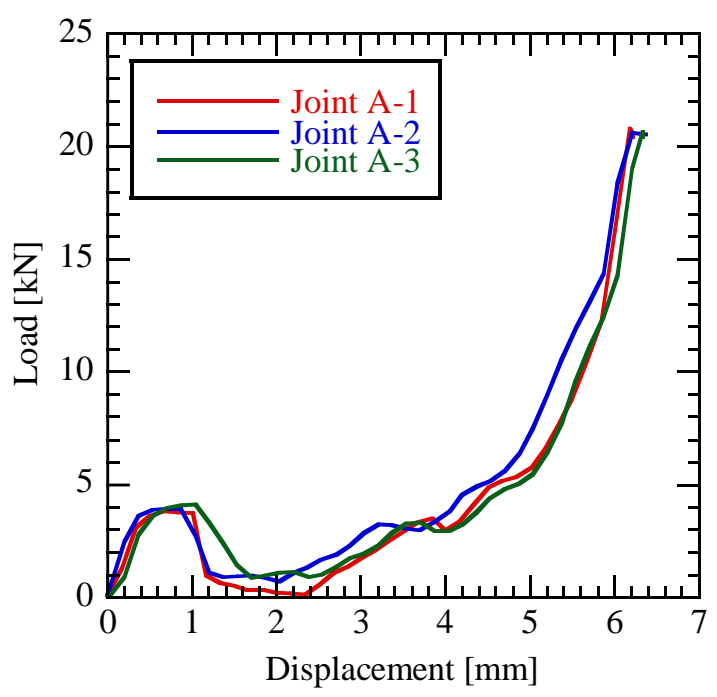

(a) Joint A

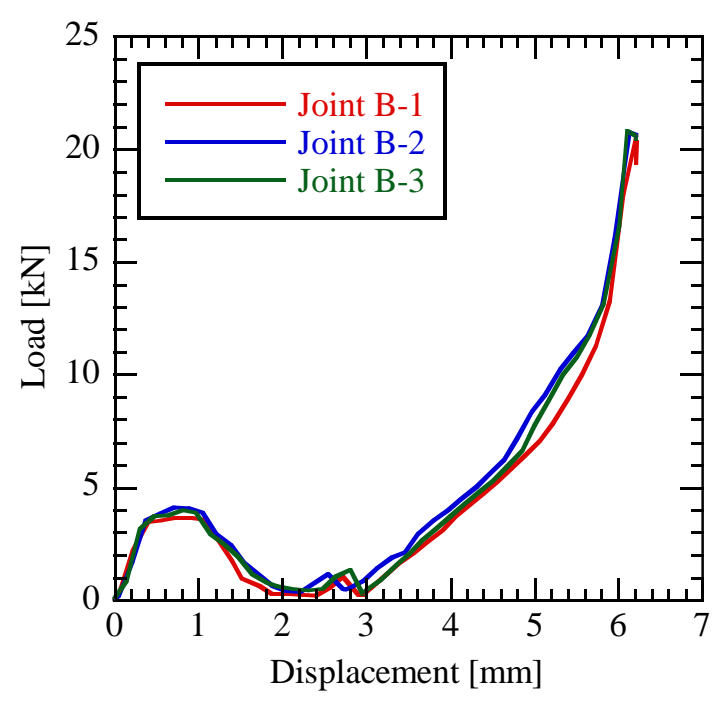

(b) Joint B

Fig.7 Load-displacement diagrams of the fastening process at the punch speed of $10 \mathrm{~mm} / \mathrm{min}$. The first rise of the load corresponded to the punching-out process of the acrylic sheet and the aluminum sheet. The second rise of the load corresponded to the rivet fastening process. 
図 8 に作製した継手の外観を示す. 図 9 には作製した継手の断面を示す. 図 8 と図 9 より, 積層順に関わらず 継手の面外変形はほとんどなく, また，アクリル薄板にも割れは見られずリベット軸先端が変形し良好に締結で きていることが確認できる. さらに, 図 10 にアクリル板にドリルで穴あけ加工した場合の穴の側面の写真の一例 を，図 11 に継手の締結部の穴の切り口面写真の一例を示寸．ドリル穴の傾は平滑な面となっている．Joint A の場合は上部の板がアクリル薄板で下部の板が A5052 薄板である. 図 11（a）から，どちらの板も破断面となっ ており凹凸が大きい．図７（a）を見ると，変位が約 $1.0 \mathrm{~mm}$ の時点で荷重が低下しており，この時点で打抜きが 終了していることがわかる. 下部の板が A5052 薄板であるためアクリル薄板の打抜き時にはアクリル薄板のたわ みが少なくなる. 下部の板の A5052 薄板のせん断過程は, リベット軸の先端にアクリルの円形小片が付いた状態 で行われているが，通常の薄板の打抜きと同様と考えられる，一方，Joint B の場合は上部の板が A5052 薄板で下 部の板がアクリル薄板である. 図 11 (b) から, 上部の A5052 薄板の切り口面は比較的滑らかなせん断面である が，バリが大きく，下部のアクリル薄板の上半分を覆っている. 図 7 (b) を見ると, 変位が $1.0 \mathrm{~mm}$ を超えても すぐに荷重が低下せず，2mm 付近まで徐々に低下している. この変位 $1.0 \mathrm{~mm} 2.0 \mathrm{~mm}$ までのせん断過程では, 下部の板のアクリル薄板の強度が低いため, 上部の A5052 薄板のせん断過程中に下部のアクリル薄板が変形して

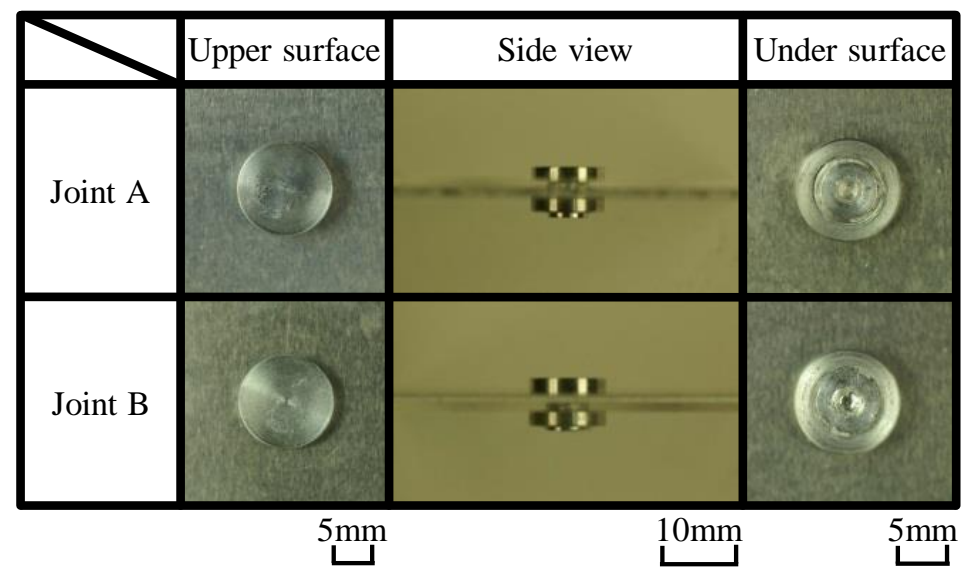

Fig.8 Appearances of fastening parts. The cracks were not generated in the acrylic sheet. The acrylic sheet and the aluminum sheet could be joined by the punching rivet method without depending on the order of the lamination of the acrylic sheet and the aluminum sheet.

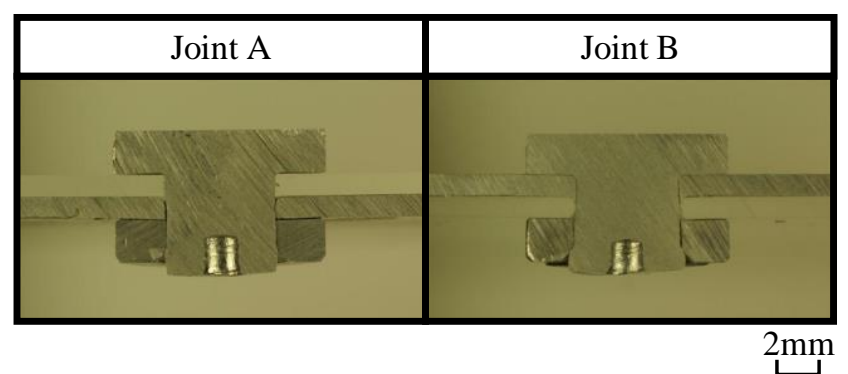

Fig.9 Cut sections of fastening parts.

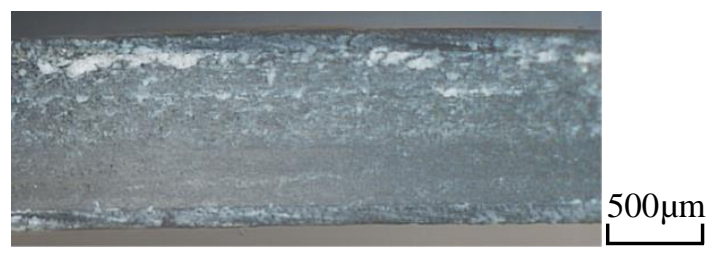

Fig.10 Wall surface of drilled hole of acrylic sheet. It had the smooth surface. 


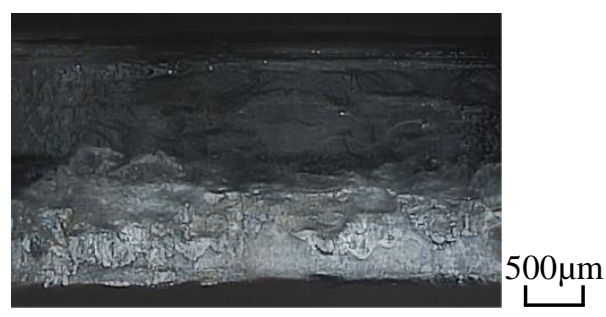

(a) Joint A

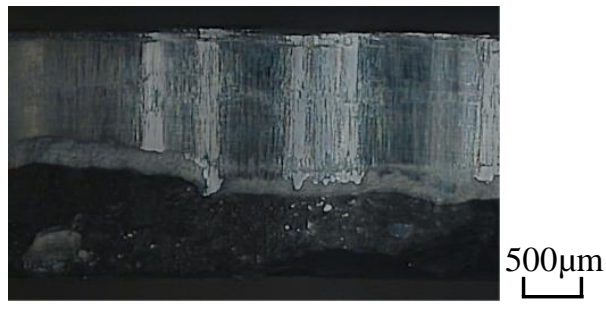

(b) Joint B

Fig.11 Cut surfaces of punched hole of acrylic sheet and aluminum sheet. Both the acrylic sheet and the aluminum sheet in case of Joint A had the uneven shape of the cut surfaces. The upper part of the acrylic sheet in case of Joint B was covered with the burr of A5052 sheet.

たわむ状態になるため A5052 薄板のバリが大きくなり, その結果, アクリル薄板を覆うようにA5052 薄板のバリ が生成されたと考えられる。これが打抜き終了までの変位が長くなることの原因であると考えられる. これらの ように，ドリル穴と打抜き穴で切り口面の状態は大きく異なっており，打抜き穴でも板の積層順によって特徵的 な違いが見られた。

\section{$3 \cdot 2$ 継手の強度}

図 12 は引張試験後の継手の破断外観の一例を示す。すべての継手において図 12 のようにアクリル薄板から破 断した. 図 13 は表 5 で示したドリル穴と打抜き穴を有する継手の強度試験から得られた最大引張荷重を示す.ま た図 14 にパンチングリベット法により作製した継手の締結強度を表す最大引張荷重を示す. 図 13 を見ると, Type $\mathrm{A}$ の 1 つのデータのみ最大引張荷重が低くなっているが，すべてほぼ同じと見ることができる. 数值としては,

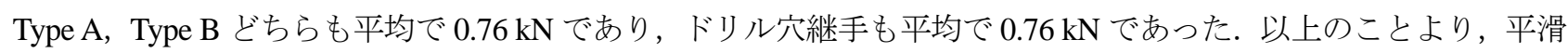
な穴でも凹凸を有する打抜き穴であっても, 強度は少しばらつきが見られるがほぼ同じであると考えられる. 図 14 より, パンチングリベット法により作製した継手の最大引張荷重の平均は, Joint A で $0.85 \mathrm{kN}$, Joint B で $0.81 \mathrm{kN}$ であり，Joint A の方が少し高くなっているが，大きな違いはなかった. Joint A の強度は図 13 の継手の強度より も約 $12 \%$ 高くなっており, ばらつきも小さくなっている. 図 13 と図 14 の違いはリベットとリベットホルダーの 座面圧力の有無である. 図 12 に示したように，継手はリベット周りのアクリル薄板の穴から破断しており，これ は，継手が引張られることでアクリル薄板の穴の縁にき裂が入り，そのき裂が進展して破断に至ったものと考え られる。つまり，パンチングリベット法により付与される座面圧力によって，アクリル薄板のき裂の進展を抑制 することができ，その結果，継手強度が向上し，ばらつきが減少したものと考えられる. なお，打抜き穴の切り 口面の状態は疲労強度に影響すると考えられることから, 継手の疲労試験を行う必要があるが, 疲労強度につい ては今後の課題としたい.

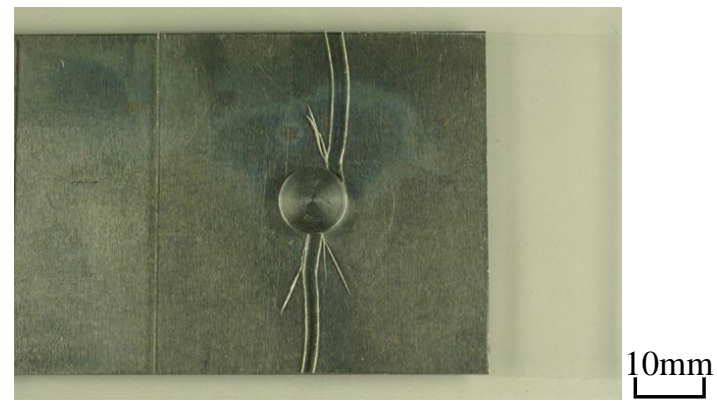

Fig.12 Appearance of fractured joint after tensile test. 


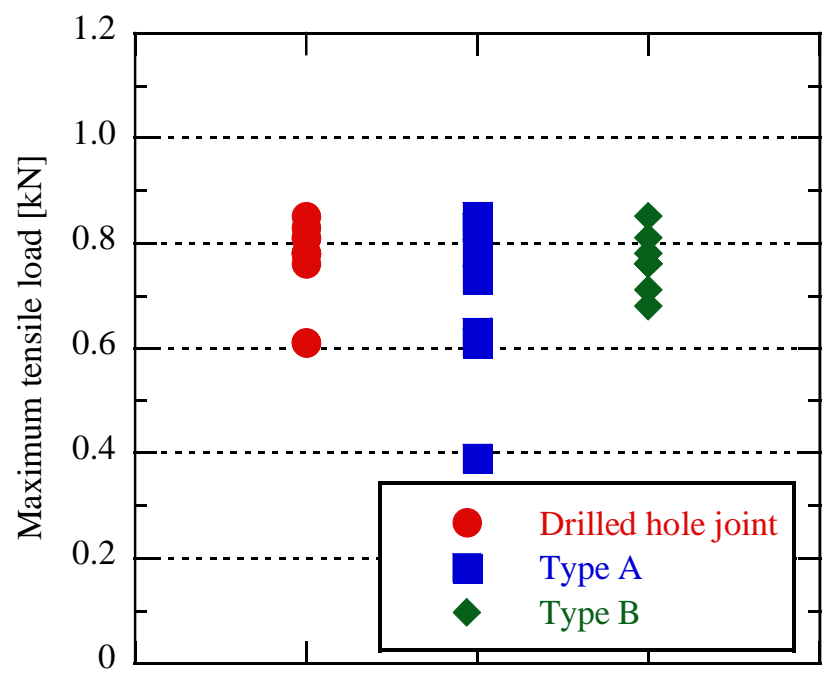

Fig.13 Effect of surface condition on joint strength. The strength of the joint with drilled hole was almost same as the strength of the joint with punched hole.

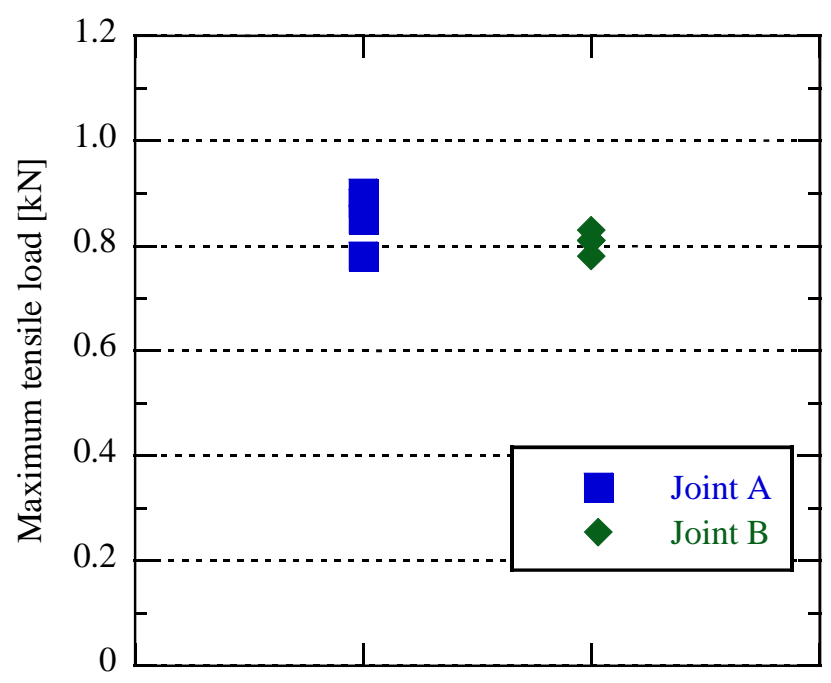

Fig.14 The strength of joints made by punching rivet method. The joint strength and its scattering were improved due to the effect of the pressures on seating faces of the rivet and the rivet holder.

\section{4. 結言}

本研究では，脆性高分子材料であるアクリル樹脂薄板とアルミニウム合金薄板をパンチングリベット法により 締結することを試み，作製した異種材継手の締結状態と強度について検討を行ったそその結果，パンチングリベ ット法により，穴あけ工程なしで脆性高分子材料であるアクリル樹脂薄板とアルミニウム合金薄板をアルミニウ ム合金のリベットで良好に締結できることを示した。 また，パンチングリベット法により付与されるリベットと リベットホルダーの座面圧力は, 引張試験時におけるアクリル薄板のき裂の進展を抑制でき, 継手強度は座面圧 力を有していない継手と比べて約 12 \%向上し，強度のばらつきも改善されることを示した.

謝辞 
本研究の一部は科学研究費補助金基盤研究（C）（課題番号 17K06123）の補助を受けたことを記して感謝の意 を表するとともに，試験片作製等に多大なご協力いただきました兵庫県立大学工作センターの職員の皆様にも感 謝申し上げます。

\section{文献}

海津浩一，木之下広幸，池田清彦，インパクトリベット，特許 4972732(2012).

片山聖二，川人洋介，丹羽悠介，丹下章男，久保田修司，ステンレス鋼と非結晶ポリアミド樹脂とのレーザ直接

接合，溶接学会論文集，Vol.25, No.2(2007), pp.316-322.

加藤亨, 安部洋平, 森謙一郎，呉宣，セルフピアシングリベットによるアルミニウム合金板と鋼板の接合，塑性 と加工, Vol.47, No.541(2006), pp.149-153.

木之下広幸，海津浩一，吉原智啓，河村隆介，池田清彦，衝撃リベット締結法による冷間圧延鋼板の接合，自動 車技術会論文集，Vol.40，No.5(2009)，pp.1309-1314。

木之下広幸，海津浩一，吉原智啓，河村隆介，池田清彦，リサイクル設計を考慮した衝撃リベット締結法，日本 機械学会論文集 C 編，Vol.76，No.763(2010)，pp.710-716.

木之下広幸，海津浩一，小林太一，池田清彦，パンチングリベット法による冷間圧延鋼板の締結，日本機械学会 論文集 C 編，Vol.77，No.780(2011)，pp.3184-3192.

西本浩司, 中村浩, 丹羽悠介, 川人洋介, 片山聖二, レーザを用いた純チタンとエンジニアプラスチック PET と の異材直接接合，軽金属溶接，Vol.51， No.5(2013)，pp.166-172.

Porcaro, R., Hanssen, A. G., Langseth, M. and Aalberg, A., The behavior of a self-piercing riveted connection under quasi-static loading condition, International Journal of Solid and Structures, Vol.43 (2006), pp.5110-5131.

日本機械学会編，機械実用便覧改訂第 5 版(1981), pp.326-331.

日本塑性加工学会編，接合一技術の全容と可能性一(1990), コロナ社，p.215.

\section{References}

Kaizu, K., Kinoshita, H. and Ikeda, K., Impact rivet, Japanese Patent 4972732 (2012).

Katayama, S., Kawahito, Y., Niwa, Y., Tange, A. and Kubota, S., Laser direct joining between stainless steel and amorphous polyamide plastic, Quarterly Journal of the Japan Welding Society, Vol.25, No.2(2007), pp.316-322 (in Japanese).

Kato, T., Abe, Y., Mori, K. and Xuan, W., Joining of aluminum alloy and mild steel sheets by self-piercing rivet, Journal of the Japan Society for Technology of Plastics, Vol.47, No.541 (2006), pp. 149-153 (in Japanese).

Kinoshita, H., Kaizu, K., Yoshihara, T., Kawamura, R. and Ikeda, K., Joining of cold-reduced carbon steel sheets by impulsive riveting method, Transactions of Society of Automotive Engineers of Japan, Vol.40, No.5(2009), pp. 1309 - 1314 (in Japanese).

Kinoshita, H., Kaizu, K., Yoshihara, T., Kawamura, R. and Ikeda, K., Impact riveting considering design for disassembly, Transactions of The Japan Society of Mechanical Engineering, Series C, Vol.76, No.763(2010), pp. 710 - 716 (in Japanese).

Kinoshita, H., Kaizu, K., Kobayashi, T. and Ikeda, K., Joining of cold-reduced carbon steel sheets by punching rivet method, Transactions of The Japan Society of Mechanical Engineering, Series C, Vol.77, No.780(2011), pp. $3184-3192$ (in Japanese).

Nishimoto, K., Nakamura, H., Niwa, Y., Kawahito, Y. and Katayama, S., Direct joining of pure titanium and engineering plastic PET with laser, Journal of Light Metal Welding, Vol.51, No.5(2013), pp. 166-172 (in Japanese).

Porcaro, R., Hanssen, A. G., Langseth, M. and Aalberg, A., The behavior of a self-piercing riveted connection under quasi-static loading condition, International Journal of Solid and Structures, Vol.43 (2006), pp.5110-5131.

The Japan Society of Mechanical Engineers ed., JSME concise handbook for mechanical engineers on the revision of the fifth edition (1981), pp.326-331 (in Japanese). 
Kaizu, Ito, Kusaka, Kimura and Kinoshita, Transactions of the JSME (in Japanese), Vol.84, No.862 (2018)

The Japan Society for Technology of Plasticity ed., Joining - detailed techniques and possibility-(1990), Corona Publishing. Co., LTD., p.215 (in Japanese). 